\title{
Prevalence of multidrug resistant tuberculosis at tertiary care hospital
}

\author{
Madhurima Pothula*, P Sreenivasulu Reddy, P Vasundhara, Vedamurthy Reddy \\ From First International Science Symposium on HIV and Infectious Diseases (HIV SCIENCE 2012) \\ Chennai, India. 20-22 January 2012
}

\section{Background}

Tuberculosis continues to plague the world and remains the major global health problem. Simultaneously the incidence of drug resistant Mycobacterium tuberculosis strains is also increasing in almost all industrialized and developing countries.

\section{Methods}

This prospective study was done at NMC, Nellore from July 2008-December 2009. Samples received at microbiology lab for acid fast staining were included in this study. Smears were stained by Ziehl-Neelsen's technique. Samples were cultured on Lowenstein-Jensen media after processing by modified Petroff's method and incubated according to CLSI guidelines. Identification of Mycobaterium tuberculosis was done based on morphology, nitrate reduction test and catalase test. Drug susceptibility for first line anti- tubercular drugs was performed by proportion ratio method.

\section{Results}

A total of 2031 samples were included in this study. 120 samples were smear positive by acid fast staining, 110 were culture positive for Myobacterium tuberculosis. 16 (14.5\%) samples were resistant to one or more antitubercular drugs. 10 (9.09\%) samples showed monodrug resistance, Isoniazid (3.63\%) followed by Rifampicin (2.72\%) Ethambutol (1.81\%) and Streptomycin (0.90\%). Isoniazid and Ethambutol resistance in one sample $(0.90 \%)$. Isoniazid and Rifampicin resistance in two samples $(1.88 \%)$. Three samples were resistant to Isoniazid and Rifampicin along with other drugs $(2.72 \%)$. HIV coinfection among MDR-TB was $2.7 \%$.

* Correspondence: chinnupreddy@rediffmail.com

Narayana Medical College and General Hospital, Nellore, A.P, India

\section{Conclusion}

According to the present study prevalence of MDR-TB was $4.54 \%$. Among the patients on treatment higher incidence of resistance was attributed to poor patient compliance in spite of effective DOTS programme.

Published: 4 May 2012

doi:10.1186/1471-2334-12-S1-P29

Cite this article as: Pothula et al:: Prevalence of multidrug resistant tuberculosis at tertiary care hospital. BMC Infectious Diseases 201212 (Suppl 1):P29.
Submit your next manuscript to BioMed Central and take full advantage of:

- Convenient online submission

- Thorough peer review

- No space constraints or color figure charges

- Immediate publication on acceptance

- Inclusion in PubMed, CAS, Scopus and Google Scholar

- Research which is freely available for redistribution
C Biomed Central
C Biomed Central 